\title{
Reception of Edward Said in Literary Study in China
}

\author{
Chunjuan Zhang \\ School of Foreign Languages \\ Shaanxi Normal University \\ Xi'an, China 710062
}

\begin{abstract}
Edward Said and his Orientalism were first introduced to China as a literary theory at the beginning of the 1990 s, a period of the awakening of Chinese cultural awareness. Said presented a new research perspective for the study of both literary theory and literary textual criticism in China. By this perspective, Chinese literary critics has put forward such propositions as "the Third World literary theory" and "aphasia of Chinese contemporary literary theory", and reinterpreted the texts of the fifth generation of Chinese film as well as some literary works of the Third World. From the Reception of Said's theory in China, it can be said that this theory is regarded as a tool for Chinese literary critics to remove the influence of the western modernity discourse and to establish the "nationality" of Chinese literary theory.
\end{abstract}

\section{Keywords-Edward Said; literary theory; textual criticism}

\section{INTRODUCTION}

The interest in Said began to increase since the early 1990s in China, though his Orientalism was not translated into Chinese until 2000, in a series devoted to Western Culture. Said's postcolonial theory had a lasting impact on cultural studies in China since its introduction. In current debates on East-West cultural relation, Said is most influential and even most quoted in China. Since the publication of Orientalism, this concept has been one of the major theoretical issues attracting the attention of Chinese scholars, and therefore it is quite safe to say that Said and his theory have changed to some extent the model of literary study in China.

\section{EDWARD SAID AND HIS ORIENTALISM}

Edward Said (1935-2003) was a professor of English and comparative literature of Columbia University. As a cultural critic, he is best known for his Orientalism published in 1978, which is later considered as a foundational work of postcolonialism.

According to Said, western orientalism can be divided into three domains: the first is an academic one, a scientific discipline in the West beginning in the early 19th century; secondly, it refers to a mode of thinking based on an ontological and epistemological distinction made between "the Orient" and" the Occident"; thirdly, it refers to a way of cultural dominance and oppression of the powerful West over the weak East, and this dominance is what Said was

This paper is a phased outcome of Social Science Project of Shaanxi Province "Humanism and Cultural Criticism-Study on Said's Cultural Criticism" (13J069) interested in. [1]

In Orientalism, Said offered a sweeping panorama of how western scholarship treated the area of the Near East and Arab world and turned it from an "alien space" into a "colonial space". He found in the history of oriental study that the Orient existed as "the other" of the West. Contrary to the "advanced" and "civilized" West, it was "barbarous", "mysterious", "uncivilized" and couldn't represent itself but only be represented by the West (which was exactly what the West had been doing for centuries). However, since Napoleon's invasion of Egypt at the end of 18th Century, the representation of the Orient by the West gradually colluded with colonial expansion and became an accomplice of western politics. Thereafter, with efforts of generations of orientalists, oriental study had descended to a national and academic fantasy of the Orient, having less to do with the actual Orient than the western world. Therefore, Said argued that orientalism was a system of representation combining oriental knowledge and western hegemony, which fashioned and created the Orient by the power of discourse. Contrary to "pure knowledge" of a scientific discipline, orientalism here was a kind of "political knowledge". Said concluded that from the late 18thcentury, the three domains of orientalism had been overlapping each other and changed the orient from "a fact of nature" to "a fact of human production", an "imaginative geography" constructed by discourse.[2] Under the control of western orientalism, the oriental countries lost their national consciousness and ended up as the vassals of western countries.

To the relationship between literature and Orientalism, Said concentrated on the novels of some major empirebuilders such as Britain, France and America in 19th and 20th century. While recognizing the great aesthetic value of these novels, Said also noticed the fact that they had entangled with the overseas colonial expansion and contributed a lot in "the formation of imperial attitudes, references and experiences".[3] He pointed out that in the empires' global colonization, novels as a form of knowledge had been assimilated as a part of imperialist ideology and they legitimized the imperialist hegemony under the mask of humanism. About the interdependent relationship between narratives and empire power, he said: "the main battle in imperialism was over land, but when it came to who owned the land had the right to settle and work on it-these issues were reflected, contested, and even for a time decided in narrative. The power to narrate, or to block other narratives 
from forming and emerging, is very important to imperialism.’'[4]

Narratives had a power to dominate, but Said realized they also had a power to liberate. He argued that narratives had already become the method that colonized people use to assert their own identity and the existence of their own history. Here comes the concept of "cultural resistance" and the issue of the construction of national culture in the Third World countries, which are two important aspects in Said's theory. In his writing, Said emphasized the significance of cultural resistance in building national culture on the one hand, and on the other, he warned the intellectuals of the destructive power of extreme nationalism and advocated his thoughts of multiculturalism, which he set as an ultimate objective of his writing and repeatedly discussed in his later works.

\section{THE SOCIAL AND CULTURAL BACKGROUND OF THE RECEPTION OF SAID IN CHINA}

Considering its research fields, Said's postcolonial theory involves literature, history, anthropology and other humanistic disciplines. But in China, it was first introduced as a school of literary theory in the early 1990s. Generally speaking, the study of Said's theory in literature consists of two aspects: postcolonial literary theory and postcolonial literary criticism. The first focuses on the concepts and categories of his thought; the second examines such issues as the relationship between the Third World national cultures and Western cultures, colonialism and anti-colonialism, and devotes itself to the cultural problems left by colonialization. As to the circle of literature in China, compared with the first aspect, the achievements in postcolonial criticism are much more prominent. The reason is mainly that the issues explored by postcolonial criticism are more in line with the cultural and political background in China at that time and thus appear more significant. In the early 1990s, when Said's postcolonial theory traveled to China, the country was deep in political and diplomatic turmoil. A considerable number of intellectuals began to probe into the problems arising in the process of cultural and social revolution during the $20^{\text {th }}$ century. They re-evaluated the cultural modernization in China since 1919 and reconsidered the status and values of Chinese traditional culture. Since then, cultural ideology in China started to shift gradually from the Enlightenment thought of the West to Chinese traditional culture. The intellectuals took the initiative to resist the influence of Western culture and criticize the radical anti-tradition literary revolution since the May Fourth Cultural Movement. Henceforth, the academic trend went from cultural radicalism to conservatism. All of these changes echoed intrinsically with Said's postcolonial theory in the aspects of resisting Western centrism and cultural hegemony and promoting national culture, and therefore provided a favorable environment for the spread of Said's theory in China. In this context, when Chinese scholars hailed postcolonialism as a new literary theory, they were concerned more about the critical functions of this theory and its application to literary criticism in China than to the theory itself, and this can be seen from the fields of literary theory study and criticism in China.

\section{THE RECEPTION OF SAID IN LITERARY THEORY STUDY}

In the early 1990s, inspired by Said's arguments on orientalism and national culture, some Chinese critics introduced a proposition "the Third World literary theory". Through the analysis of literary criticism and teaching in China, they argued that with the incoming of Western culture, some "global" discourse had penetrated into Chinese literary criticism and brought potential damages to the traditional one, the result of which was that Chinese literary theory gradually lost its position in interpretation and retreated from academic discourse. In this regard, some critics advocated to resist against the critical discourse of the First World by "an insightful theory that was featured with local characteristics and literary tradition". $5^{1}$ This "insightful" theory was "the Third World literary theory". It attached much importance to language convention and cultural traditions of the Third World countries and considered the contradiction between East and West was a principal one in contemporary literary study in the Third World. As to China, a prominent theme of Chinese contemporary literature was the cultural depression and resistance between the First World and Third World.

The Third World literary theory was a first attempt for Chinese critics to apply Said's postcolonial theory to literary study in China. It was the first time for the critics to examine the development of Chinese modern and contemporary literature from the relationship between the First World and Third World. Early Chinese postcolonial critics had high expectations for this theory. They hoped that it would transform Chinese literary theory from a dependent status to an independent one.[6] However, due to the lack of a classification standard and the uncertainty of its research object, it was abandoned soon after it was adopted.

After the Third World literary theory, driven by the prosperous development of Said's theory in China, the discussions on colonialism and anti-colonialism, modernity and nationality continued and grew up to a frontline topic in the field of literary study. In the mid-1990s, some scholars of comparative literature launched a series of propositions under the title of "the aphasia of Chinese contemporary literary theory" and discussed them as "development strategies of Chinese literary theory in the 21 st century". Even so far, after 20 years' arguments and debates, these topics are still alive in China.

For the advocates of this proposition, literary aphasia in China was a kind of cultural sickness. It referred to the fact that Chinese critics had lost their voice in literary interpretation and therefore they couldn't express themselves with their own terms but only relied on Western discourse. For this situation, the critics asserted it was a result of literary "orientalism". They argued that in the production of literary theory in China, due to the sweeping impact of Western culture and the longing for Westernization or modernization in China, most critics have abandoned Chinese traditional discourse and indulged themselves in the "more advanced" Western theories.[7]The consequence was that decades later, they found themselves in between two discourses: on the one hand, they could never catch up with 
the pace of Western theories, and on the other hand, they had already drifted far away from their own resources. This situation of literary study led to the so called "literary aphasia".[8] In response to this sickness, the critics proposed "the modern conversion of Chinese ancient literary theory" and "the sinicization of Western literary theory" as remedies, ${ }^{1}$ which till now, are still under discussion and no feasible method has been founded.

As a major branch of Chinese postcolonial criticism, the proposition of "the Third World literary theory" and "literary aphasia" expressed the impulse of returning to "the true orient" in the study of literary theory, they also implied the anxiety for originality in Chinese contemporary literary study.

\section{THE RECEPTION OF SAID IN LITERARY TEXTUAL CRITICISM}

Besides literary theory, literary textual criticism in China in the last two decades also witnessed the impact of Said's postcolonial theory. For Chinese contemporary literary criticism, Said's postcolonial theory opened up a new perspective and was applied frequently to the criticism of film literature, especially that of China's fifth-generation directors represented by Zhang Yimou.

Beginning in the late 1980s and early 1990s, China's fifth-generation directors sprung up and won a series of international awards. At the same time, Said's postcolonial theory began to rise in China. Because of the emphatic descriptions of Chinese folklores and old-fashioned customs in Zhang's films on the one hand and their popularity in the western countries on the other hand, these films soon fell into the hands of Chinese critics and became the target of repeated criticism. For the critics, Zhang is suspected of having the intention of "self-orientalism".[10] In order to attract the attention of the western audience, Zhang abused Chinese special historical and cultural resources and intensified or even invented the so called "Chinese folklores". They believed that by creating a distant and mysterious China, a strange society and nation as "the other" of western countries, Zhang's films lived up to Western people's fantasies of China. Therefore, the critics asserted that Zhang's "implied readers" were not Chinese people but the western audiences and critics and his successes depended largely upon his being recognized by Western critics.

\footnotetext{
${ }^{1}$ Some related major studies are as follows:
}

Shunqing Cao, Siqu Li, The Basic Ways and Methods in Rebuilding Chinese Literary Discourse, Literature and Art Studies, 1996(2), p.12-21

Yu Gao, "Alogia" Status in Chinese Literary Theory and the Possibility of"Reconstructing", Journal of South China Normal University, 2010(5), p70-76.

Xian Zhou, Legitimacy Debates and Identity Crisis-In the Case of "Aphasia" in Chinese Modern Literary Theory and "Westernization" of Chinese Modern Poetry, Journal of Nanjing University (Philosophy, Humanities and Social Sciences), 2006(5), p.98-107.

Yinggang Gao, Retrospection and Reflection on the Debates of "Aphasia", Journal of Literature, History and Philosophy, 2010(6), p. 111-119.

Yanfeng Li, Jifang Duan, On“Aphasia”Of Chinese Literary TheoryTheory Introspection of the "Discourse Event", Research of Chinese Literature, 2014(4), p.19-23.
In fact, when criticizing Zhang Yimou for his "catering to" a western audience, Chinese postcolonial Critics are not well founded. From the acceptance of Zhang's films in the western world, instead of "hunting for novelty in China", the critics were concerned more about the cultural and political implication in Zhang's films. In the fermentative atmosphere of postcolonial study, some critics became more sensitive to the concepts like "cultural colonialism", "cultural identity" and "nationalism".

Another field for the application of Said's postcolonial theory in literature criticism is the Third World literature. As a part of cultural modernization, the study of foreign literature in China started at the beginning of the 20th century. The purpose of the study was to learn "advanced culture" from the West. Therefore, "foreign literature" at that time was almost equivalent to that of some major western countries, especially British and American literature. Literature of other regions such as Africa, Caribbean and Australia was almost ignored. In the late 1990s, with the introduction of Said's theory, the Third World literature began to catch the attention of Chinese critics and arise gradually in literary criticism. Till now, there are totally 160 journal papers and 15 graduation theses of $\mathrm{PhD}$ and $\mathrm{MA}$ researching the Third World literature from a postcolonial perspective, most of which focused on Nobel laureates such as V.S Naipaul and J.M. Coetzee. The subjects of the postcolonial literary criticism varied greatly, from the relationship between the suzerain and colonial cultures, the anxiety for cultural identity to the construction of national culture of the Third World after political independence.

In addition to film literature and the Third World literature, there are other fields such as sinology ${ }^{2}$ that have been discussed by Chinese postcolonial critics.

\section{CONCLUSION}

In summary, because of the semi-colonial experiences and the cultural background at the end of last century, Edward Said was unprecedentedly welcomed in the circle of literature in China. In some degree, this indicates the awakening consciousness of the knowledge innovation and academic independence of Chinese scholars. But on the other hand; it also exposed their weaknesses, of which a distinct one is nationalism and cultural conservatism. For Chinese critics, the complex relationship between nationality and modernity, modernity and postcoloniality has always been a

\footnotetext{
${ }^{2}$ Some related major studies are as following:

Kuan Zhang, Said's “Orientalism” and Sinology in the West, Liao Wang, 1995(27), p.36-37.

Mingdong Gu, Critical Re-Analyses of the Problems in the Theory and Practice of Sinologism: Towards Self-conscious Reflections and as Fair and Objective Knowledge Production as Possible, Jounal of Xiamin University (Arts \& Social Sciences), 2015(4), p1-13.

Mingdong Gu, Sinologism: An Alternative to Orientalism and Postcolonialism, London and New York: Routledge, 2013.

Xiping Zhang, Debates on Sinology and "Sinlologism", Journal of Shanghai Normal University (Philosophy and Social Sciences Edition), 2015(3), p.21-36.

Ning Zhou, Sinology or Sinologism, Journal of Xiamen University (Arts \&Social Sciences), 2004(1), p.5-13.
} 
tricky problem since the beginning of 20th century. How to keep a balance among these issues and avoid going further to the extreme of cultural nationalism and then cultural conservatism is a question they should approach cautiously.

\section{REFERENCES}

[1] E. Said, Orientalism, London: Penguin Books, 1978, p.2-3

[2] E. Said, Orientalism, London: Penguin Books, 1978, p.12.

[3] E. Said, Culture and Imperialism, New York: Vintage Books, 1993, p.Vii.

[4] Yiwu Zhang, Recourse at the Edges - Third World Culture and Contemporary Chinese literature, Beijing: The Times Literary Press, 1993, p.147.

[5] Yiwu Zhang, The End of Modernity, Strategy and Management, 1994(3), p.167

[6] Xianlin Ji, Oriental Theory Anthology, Comparative Literature News, 1995(10), p.7.

[7] Shunqing Cao, Literary Aphasia and Cultural Sickness, Literary Contention, 1996(2), p.50-58

[8] Yiwu Zhang, Zhang Yimou in the Context of Global Postcolonialism, Contemporary Film, 1993(3), p.18-25.

[9] Yiwu Zhang, Zhang Yimou and the Global Imagination, Literary Contention, 2005(1), p.79-84.

[10] Shenqin Cai, Xin Zhou, Orientalism of Director Lee Ang in His Film, Jounal of HUST (Social Science Edition), 2001(4), p.86-89. 